\title{
The Need Analysis of Development of Local Excellence-based Science Instructional Materials for Elementary Schools
}

\author{
${ }^{1 s t}$ Nurratri Kurnia Sari \\ Study Program of Elementary Education \\ Universitas Veteran Bangun Nusantara \\ Sukoharjo, Indonesia \\ nurratrikurniasari@univetbantara.ac.id
}

\author{
${ }^{2 n d}$ DwiAnggraenySiwi \\ Study Program of Elementary Education \\ Universitas Veteran Bangun Nusantara \\ Sukoharjo, Indonesia \\ dwianggraenisiwi@univetbantara.ac.id
}

\begin{abstract}
The present research aims at describe preliminary condition of science learning in subdistricts of Sukoharjo and need analysis to develop Sukoharjo local excellence-based instructional materials. Data were taken using such methods as interview, observation, and documentation analysis. The development of instructional materials applied Plomp'sdevelopment model. The first step of the model is analysis, that is preliminary study on how the science learning runs. In reference to analysis of the findings, printed instructional materials will be designed and this will be the development of instructional materials. Based on the analysis results, it can be concluded that: a) profile of competence standards and basic competence indicates that the science learning for elementary schools involving the learning of science, environment, technology, and society, directed to learning experience to design and make a work through implementation of science concept and scientific work competence, b) a concept relevant to local excellence of Sukoharjo is the form of matter and its change, c) the field analysis of science learning in elementary schools proves that the use of instructional materials which relate Sukoharjo local excellence has not yet been optimized, and therefore students have not yet known local potentials in their region, d) according to field analysis, teachers require instructional materials which meet students' individual learning needs, make students independent by adjusting to the surrounding regions.
\end{abstract}

Keywords-Instructional Materials, Science Learning, Local Excellence Education

\section{INTRODUCTION}

Synergy between world of education and real world in society is highly required. Knowledge and skills developed in schools are also needed to be improved in society to make them relevant and synergistic with their needs. Education is expected to increase society's degree of life, both at the side of knowledge and at the side of contextual problem solving. During this time, education has not yet met all society's demands, particularly in the field of life skills which fit to students' local life conditions. Instructional materials are not often in line with society's development and needs. As a consequence, after graduating, students cannot directly apply theories they obtained.
Innovation in science learning for primary schools is needed since most science learning patterns insufficiently make use of local excellence as a learning source, especially in the regency of Sukoharjo. This aims at developing local potentials so that the local sources can be exploited for society and the region itself. Education has not yet met all society's demands, particularly in the field of life skills which fit to students' local life conditions. Instructional materials are not often in line with society's development and needs. Such actions should be responded by government as concrete actions to develop local potentials. Society should be involved and actively participate to realize local excellence-based education so that it can be useful for region and society wealth. The local excellence of Sukoharjo which can be referred as contexts in instructional materials of practical works includes: a) the making of instant jamuremedies at Nguter, Sukoharjo, b) the making of batik at KedungGudel, Sukoharjo, c) the making of gamelan (a traditional instrumental ensemble) at Bekonang, Sukoharjo, d) the making of wayang (puppets) at BulakRejo, Sukoharjo, and e) water cycle processes at Mulur, Sukoharjo.

Instructional materials serve as one of important parts in learning process. they are parts of learning sources which contain learning messages, either specific or general and can be used for learning. [15] Instructional materials involve all kinds of materials, information, instruments and texts used to help teachers/ instructors perform learning and teaching activities. [1] The materials can be either written or unwritten. Instructional materials are a set of information absorbed by learners through fun learning. [14] This indicates that the drafting of instructional materials is expected to take advantages for students into account.

The development of instructional materials and that of textbooks are two inseparable things since instructional materials are materials used by students during learning process according to learning targets. Textbooks serve as the sources of instructional materials. Textbooks are developed generally, while learning materials are developed according to characteristics of the learning. The development of instructional materials should be guided by content standards, 
while that of textbooks should refer to the instructional materials needed. [20]

Seven principles of instructional material development include: a) gradual (carried out through several steps from clustering types of subjects to determining contents of each subject), b) comprehensive (carried out by viewing contents of each subject comprehensively), c) systematic (carried out by viewing contents of a subject as an intact unit passing through continuous process), d) flexible (able to accept new things which have not yet been covered by contents of subject), e) scientific validity (constructed based on the validity level of ordered topic sequence and reliable described connection, f) learner-oriented (fit to the learners' characteristics and consider learners' needs and interest, and g) continuous (instructional material development is continuous process which connects such activities as designing, evaluating, and using. [7]

Learning strategies apply general framework of teacher and student activities in realizing learning and teaching activities. The learning strategy using practical work is a learning concept which helps teachers connect the materials being taught and students' real world, and encourages students to interact with their knowledge. The method of practical work is a teaching method which gives an opportunity for students to do practical work to prove or test theories they have learnt. Since practical work is inseparable from science learning, science is known as experimental science. [20] The method of practical work presents several advantages, particularly for students, and is considered essential in developing students' learning and students' skills of scientific investigation. Therefore, it can be applied to improve science learning and teaching process through an approach which emphasizes the way facts, concepts, principles, laws, and theories are obtained. Students are required to experience themselves. [3]

If associated with the readiness of technology users, science is a component which helps improve the readiness of society's knowledge of technology products. In addition, science plays role in enhancing society's knowledge of the use of natural resources, or in improving society's understanding of natural phenomena occurring in their everyday life. [17]

Local excellence refers to potentials of a region to be valuable products or services and to add local revenue, which are unique in nature and have competitive excellence. It is whatever with typical local characteristics involving such aspects as economy, culture, information technology and communication, ecology, etc. [4]One way to become a developed country is to exploit its own sources, natural richness, and culture to achieve independence and self confidence. Therefore, government is initiating local excellence-based education to be implemented in the learning. such education makes use of local excellence in such aspects as economy, culture, information technology and communication, ecology, etc, which are useful for development of students' competence. [8]

Local wisdom cannot merely be interpreted as hereditary knowledge based on experience. It reflects how people behave by considering the existence of nature. It serves as a basis to develop environment better with the use of the latest technology. [10] The system of knowledge oriented to typical language of nature for a region is local wisdom. Since ancient times, nature, human, and environment are closely related. An advance in technology puts interaction and communication among nature, human, and built environment at a distance. It is not intended to imitate past time architecture, but to understand language of nature, human, and built environment which generates creative and innovative works. [16]

The local excellence of Sukoharjo which can be contexts in realistic mathematics learning includes: a) the making of instant jamuremedies at Nguter, Sukoharjo, b) the making of batik at KedungGudel, Sukoharjo, c) the making of gamelan (a traditional instrumental ensemble) at Bekonang, Sukoharjo, d) the making of wayang (puppets) at BulakRejo, Sukoharjo, and e) water cycle processes at Mulur, Sukoharjo.Instructional material development of local product-based science practical work in Sukoharjo is expected to empower society to be learning objects. Empowerment means evoking sources, opportunities, society's knowledge and skills to improve capacity in determining their future. [20] The main concept contained in empowerment is how to give broad opportunities for society to self-determine life direction in their community.

Empowerment emphasizes on autonomy in decision making of a group of society. The implementation of aspects of democracy and participation with focus point of locality will be a framework for attempts to strengthen local potentials. In this case, society empowerment also focuses on the strengthening of individuals, society, and institutions. The main approach in the concept of empowerment is putting society not only as objects, but also as subjects. Society empowerment should lead to better society's cognitive condition formation. The nature of cognitive condition is cognitive skills underlain by individuals' or society's knowledge and insight to seek solutions to problems being encountered. Cognitive condition refers to society's formed behaviors directed to behaviors sensitive to development and empowerment values. Affective condition is the intervention of society's sense to achieve independency of attitudes and behaviors. Psychomotor skills are society's skills to support society to conduct development activities.

The aim of the problems of the research is to describe preliminary condition of science learning in subdistricts of Sukoharjo and need analysis to develop Sukoharjo local excellence-based instructional materials.

\section{METHOD}

The study applied development research method. The method is oriented to product development of which process is described as conscientiously as possible and final product is evaluated. [19]The research belongs to preliminary experimentation of development and the design is development design. Due to the limitation of fund, the research is limited to need analysis which aims at finding out preliminary analysis of draft development of instructional materials of local wisdom-based science practical work. The location of the research is elementary schools in village of Sukoharjo. Each location had different heterogeneity, environment, and customs, and therefore it was considered in 
determining research samples as trial locations. The research population includes all eight teachers of third grade of government elementary schools in the village of Sukoharjo. Technique of data collection is an instrument used/ required in carrying out research. The technique of data collection of the research involved documentation study, lists of activities, interview, and observation. The research data are qualitative data. For that reason, data were processed using descriptive qualitative method; it was applied on data which required narrative meaning making, either in contents or in process.

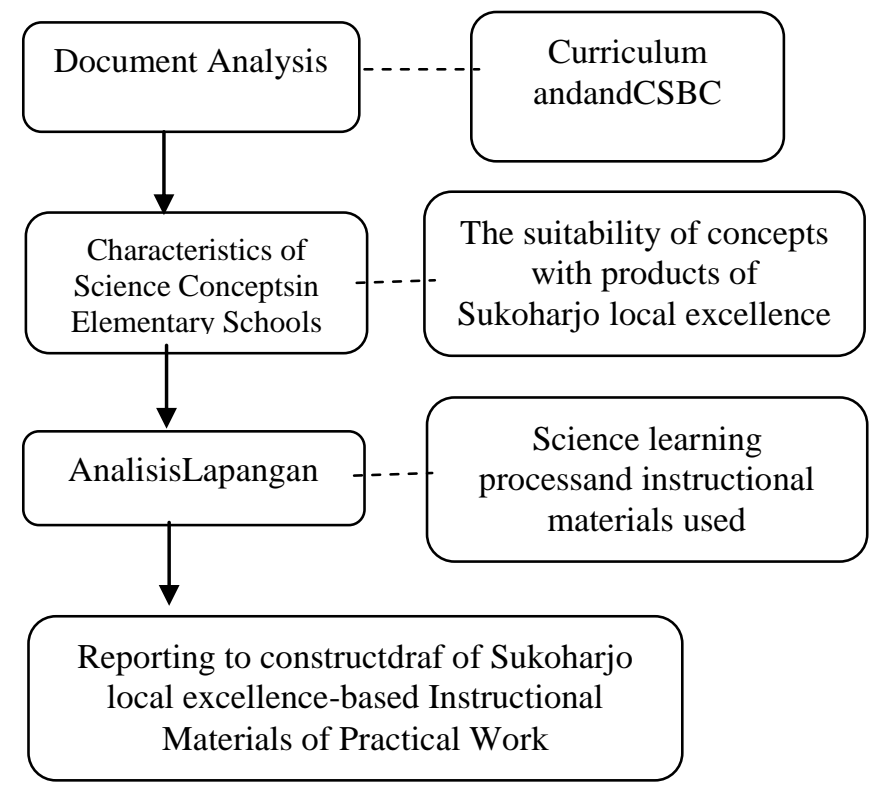

Image 1. Research Cycle

\section{RESEARCH RESULTS}

The research results serve as a guide in developing textbook of Sukoharjo local excellence-based science practical work.

\section{A. Document Analysis}

Document analysis involved analysis of curriculum used in elementary schools in the village of Sukoharjo. One of important components of education is curriculum. Curriculum is th component of education referred by educational units, either education managers or education administrators, especially teachers and principals. The depth of curriculum contents on each subject in every educational unit is reflected in competence mastered by learners in accordance with study load included in curriculum structure. The competence covers competence standards and basic competence developed with regard to competence standards of graduates. Basic competence and competence standards are abilities which should be mastered by students on certain subject as reference to construct indicators.

Competence Standards and Basic Competence expressed in content standards contain minimum grade boundaries achieved by learners during their learning process. This implies that teachers should perform the presentation of materials better either in class or outclass and has implication on teachers' competence. If teachers feel that they are less competent in terms of Competence Standards and Basic Competence, they need to learn so that they can facilitate students' learning optimally. Each Competence Standard and Basic Competence should be given meaning appropriately before being outlined to be indicators and learning objectives. For that reason, the educative messages of Competence Standards and Basic Competence are successfully conveyed.

One of the objectives of science learning for elementary schools is emphasized on the learning of salingtemas (Science, environment, technology, and society) directed to learning experience to design and create a work through the implementation of science concepts and scientific working competence wisely. This serves as a basis to determine the feasibility of instructional materials or certain competence taught through Sukoharjo local-excellence science practical work.

Basically, science learning is a learning which denotes natural phenomena at surrounding environment. In order to achieve Basic Competence and Competence Standards, actual learning at surrounding is required. according to the results of the interview with teachers at SekolahDasarNegeri 02 Sukoharjo and SekolahDasarNegeri 04 Sukoharjo, the learning process has involved practical work at surrounding environment of the schools. Teachers still use textbooks and BSI provided by government. Specific instructional materials used in science practical work have not been available.

\section{B. Characteristics of Relevant Science Concepts}

Science concepts have been widely applied to local production in Sukoharjo. The concepts are taught in science practical work at schools. They should be selected with regards to their urgency on local products of Sukoharjo and technological relationship used in the concepts at schools, and therefore they need to be introduced to students. The science concepts used in relevant technology of local production are integrated into science learning in elementary schools and explained based on groups of review materials.

There are several concepts in science learning of Third Grade of elementary schools; environmental maintenance and change in properties of matter. Some of the science concepts have been used to produce local products of Sukoharjo such as jamu remedies, batik, gamelan, and the use of waduk (reservoir) Mulur. The concept which is the most frequently applied in the process of local production is forms of matter and the change in forms of matter. Such concept indirectly teaches us about the use of matter found in surrounding areas.

The results of interview indicate that teachers have applied practical work in science learning but they have not yet introduced local products which will be their own national heritages. Students as interviewees admitted that they had not known about local products developed by their own region and how the process of the production was related to the science concepts.

The instructional materials were merely taken from science textbooks, so that the development of science concepts in surrounding environment is not optimum. The use of science 
textbooks makes teachers rigid in applying practical work; they cannot develop the instructional materials out from the textbooks, the science learning can be related to local products developed. On such process, a science concept was found: the change in form. On jamu making process, the change in the form of matter is identified: melting, freezing/ crystallizing, and evaporating. Meanwhile on the context of environment of wadukMulur, the difference in the form of matter is found: solid, liquid, and gas.

Several strategic local wisdoms introduced in the learning of the forms of matter and the change include the difference in the forms of matter and the change in the forms. For example, the difference in the forms of matter in environment of wadukMulur involves rocks, water, and air. In addition, batik making related to the change in the forms can also be taught. To teach the forms of matter and the change, local wisdom of Bali in producing local products and preserving environment through practical work is described.

\section{Field Analysis}

Teachers' skills to teach science are diverse. Although science curriculum applied in schools refers to the mastery of competence, teachers tend to teach science which is subjectoriented. In reference to the results of field observation at SD NegeriSukoharjo 02 and SD NegeriSukoharjo 04, practical work is implemented. The practical work has been connected to surrounding areas and the instruments and materials are prepared by teachers. Teachers of the Third Grade of SD NegeriSukoharjo 02 and SD NegeriSukoharjo 04 conducted the practical work by referring to the existing textbooks. In fact, specific instructional materials of the practical work have not been available yet.

The learning is still centered on the use of textbooks published by the Ministry of Education and Culture. The results of interview with teachers of the Third Grade of SD NegeriSukoharjo 04 indicate that they find it difficult to explain or to give examples on something which is often or even never found in the surrounding areas. In addition, they need modules containing local excellence of Sukoharjo, so that they will not find difficulties in giving examples in accordance with environment and in giving real examples students can found in their surrounding areas.

Science materials which have the highest priority to be taught to students include the mastery of facts, and respectively the teaching of concepts, theory, calculation, and the application of the concepts/ principles. Therefore, science teaching in elementary schools, according to students, is dominated by the introduction to facts and concepts, and is seldom connected to the application in real life.

According to the results of interview with teachers, their top priority is to teach the understanding of concepts, and the subsequent ones include facts and the mastery of theory. Thus, it follows that science learning in elementary schools emphasizes less on the use of the scientific knowledge, including on how to solve students' everyday problems. Furthermore, related to science learning as a process, general scientific skills are taught to students. Meanwhile, according to students, their priority is observing, and subsequently inferring, and classifying.

Based on the observation results, the skill of posing a question is insufficiently emphasized. According to science teachers, types of process skills taught to students are various, but there has been a tendency that observing is the top priority, while designing and experimenting are the second and third priority. In contrast, for students, drawing conclusion on observation results tends to be insufficiently prioritized. However, Similar to students' view, skills of communicating investigation results and posing question tend to rarely be given emphasis. on contrary, skill of formulating hypotheses is insufficiently trained.

The main learning source used by teachers and students is science textbooks funded from BOS (school operational funding), or so-called bukupaket (textbooks). Meanwhile, ebooks provided by the Ministry of Education and Culture have not yet been utilized by teachers and students. In addition, teachers do not connect instructional materials to science concepts and the excellence of local products since they are unfamiliar with innovative learning models with contents and contexts of local culture. The learning models they have recognized are those originated from Western countries. Analysis of sample of Lesson Plan done by science teachers indicates that in teaching science, teachers have tried to make student-centered Lesson Plan by implementing learning in accordance with the characteristics of instructional materials.

Assessment merely measures the mastery of concepts, which can be understood by students by reading books instead of doing practical work. Besides, there is a tendency that teachers merely use Lesson Plan formulated by Deliberation of Subject Teachers (MGMP-Musyawarah Guru Mata Pelajaran). The format of MGMP's Lesson Plan which still serves as guideline for science teachers has not yet been adjusted to the Regulation of Minister of National Education No. 41 of 2007, and therefore it does not reflect such processes as exploration, elaboration, and confirmation. The supporting resources investigated in the research involve science kit, learning media, as well as teachers' and students' textbooks available in each school. The availability of types of instruments and materials for science practical work on each school is between $12.2 \%$ to $100 \%$ with such conditions as damaged to good.

The main learning source used is one of science textbooks published by a publisher. The books are funded through BOS. Although it is constructed to fulfill demands of the schoolbased curriculum, it has science concepts which should be memorized by students. Therefore, it is not different from science textbooks written to fulfill previous curriculum oriented to the mastery of materials. Activity of examining given aims at strengthening the mastery of concepts, and therefore it is deductive in nature. Questions given in Competence Test only measure the mastery of science concepts, require memorization, do not demand reasoning, and insufficiently measure the mastery of students' science process skills. Although the book is constructed based on the schoolbased curriculum, it contains science materials as a product 
(facts, concepts, and theory) and does not train the mastery of science process skills.

\section{DISCUSSION}

Document analysis on science curriculum of elementary schools, especially competence standards and basic components, gives big opportunity to develop instructional materials of practical work and learning related to potentials of local excellence and the environment. This is in line with the statement [7] "The school-based curriculum gives opportunity and authority to education managers to adapt, modify and contextualize curriculum according to potentials and needs of field, including integrating real science concepts to school science learning.

The implementation of science learning based on schoolbased curriculum should prioritize the process of invention to understand surrounding nature. This can be a chance to introduce local products of Sukoharjo to students of elementary schools while practicing how to make the products. In learning science through practical work, students can experience themselves. Meanwhile, learning using method of lecturing causes instruments and materials as well as learning media to be rarely used, or even to be damaged in storage place. The limitation of the use of equipment and practical work materials retards teachers to implement science practical work. If teachers invite students to do practical work, the types of science process skills taught may include: observing, classifying, and inferring. Such types are basic skills which naturally can develop in everyday's practice of students as individual human, social human, and a part of nature. [20]

A textbook used is that funded by BOS. The contents of science used as main learning source for students are not far different from science textbooks used to support the implementation of the 1994 Curriculum. Such books contain descriptive knowledge such as facts, concepts, and principles of science with colorful images to arise motivation and students' understanding. In addition, Lesson Plan made by teachers in group of MGMP is similar and has not yet considered potentials and school environment as expected in school-based curriculum.

Local wisdom means harmonious relationship among human, nature, and built environment in region influenced by culture. The phenomena of globalization and modernization make architecture more universal and create homogenous culture. With globalization, the existence of local wisdom is questionable, especially in the built environment as a result of human culture. For that reason, the present research aims at assessing local wisdom in the built environment in globalization era [10]. Science curriculum-based learning in formal schools has put students at distance with their culture, so that they are unfamiliar with their own habitat. The surrounding environment can be learning to improve the quality of life from time to time. [9]

The findings of the research practically can $b$ followed up by schools to manage the implementation of the school-based curriculum. For example, in making lesson plan, teachers should follow process standards according to the Regulation of Ministry of National Education No. 41 of 2007, and include processes of exploration, elaboration, and confirmation in core activities. Teachers should also try to escape from psychological obstacle: feeling dissatisfied before giving more information to students through method of lecturing. Teachers should also explore local potentials and needs feasible to be integrated in science learning, and therefore the learning can be contextual, meaningful, fun, and continuous, without change in teachers' attitudes, the implementation of schoolbased curriculum will fail.

\section{CONCLUSIONS}

In reference to the analysis results, it can be concluded that: a) profile of competence standards and basic competence indicates that the science learning for elementary schools involving the learning of science, environment, technology, and society, directed to learning experience to design and make a work through implementation of science concept and scientific work competence. It serves as a basis to determine feasibility of instructional materials or certain competence taught through Sukoharjo local excellence, b) a concept relevant to local excellence of Sukoharjo is the form of matter and its change, c) the field analysis of science learning in elementary schools proves that the use of instructional materials which relate Sukoharjo local excellence has not yet been optimized, and therefore students have not yet known local potentials in their region, d) according to field analysis, teachers require instructional materials which meet students' individual learning needs, make students independent by adjusting to the surrounding regions. This is so to make students know local wisdom existing in their region, so that they will love and be proud of the potentials and local wisdom of their region.

\section{Acknowledgment}

Alhamdulillahirabil 'alamin, the researcher expresses his highest gratitude to Allah subhanahuwata'ala for blessing, love, opportunity, health, and mercy to complete this article. This article entitled "The Need Analysis of Development of Local Excellence-based Science Instructional Materials for Elementary Schools" is submitted as the final requirement in accomplishing undergraduate degree at PGSD, FKIP, Bangun Nusantara Veteran Univercity

\section{Reference}

[1] Abdul Majid, "Perencanaanpembelajaran". Bandung: RemajaRosdakarya, 2007

[2] Abdul Majid, "Perencanaanpembelajaran", Bandung: RemajaRosdakarya, 2007

[3] Abrahams, I, "Does practicalworkreallymotivated? A study of the affective value of practical work in secondary school science" International Journal of Science Education 31 (17), 2009, pp 2335-2353

[4] Amri, Sofyan, dkk, Implementasipendidikankarakterdalampembelajaran", Jakarta:Prestasti Pustaka,2011

[5] Antariksa.

"Kearifanlokaldalamarsitekturperkotaandanlingkunganbinaan. National Seminar "KearifanLokal (Local $\quad$ Wisdom) dalamPerencanaandanPerancanganLingkunganBinaan" PPI RektoratUniversitasMerdeka Malang, August 7, 2009 
[6] Antaryama, I GustiNgurah, "Bahasaalam, manusiadanarsitektur di daerahtropislembab: Sebuahrujukanuntukperancanganarsitektur di Indonesia. In proceeding of National Seminar "KearifanLokal (Local Wisdom) dalamPerencanaandanPerancanganLingkunganBinaan. August 7, 2009, Major of Architecture Technique ofUniversitasMerdeka Malang

[7] Arlitasari, O., Pujayanto, P., \&Budiharti, R., "Pengembanganbahanajar IPAterrpaduberbasis Salingtemasdengantemabiomassasumber energialternatifterbarukan", JurnalPendidikanFisika, 1(1), 2013

[8] Asmani Jamal Ma'mur, Pendidikanberbasiskeunggulanlokal. Yogyakarta: Diva Press, 2012

[9] Dedi dwitagama,2007. Pendidikanberbasiskeunggulanlokal\&global. [Online]. Available: http://dedidwitagama.wordpress.com/2007/11/07/ pendidikan-berbasis-keunggulan- lokal-global/. [April 9, 2016]

[10] Dahliani.,Faqih, Muhammad., andHayati, Arina, Changes of architectureexpressions on Lanting House based on activitysystem on the river. History Research 2015; 3(1): 1-8. Science Publishing Group, 2015

[11] Edress, Munichy B., Local wisdomfor sustainablearchitecture (MempertemukanTeknologiDenganKearifanLokalSebagaiPenggerakArs itekturBerkelanjutanPadaLingkunganBinaan). In proceeding of National Seminar "KearifanLokal (Local Wisdom) dalamPerencanaandanPerancanganLingkunganBinaan" August 7, 2009. Major of Architecture Technique ofUniversitasMerdeka Malang.

[12] Haigh, M, "Can investigativepracticalwork in highschoolbiologyfostercreativity?, Research in Science Education 37 (2), 2007, pp123-140

[13] Högström, P., Ottander, C., and Benckert, S, "Lab work and learning in secondaryschoolchemistry: The importance of teacher and studentinteraction", Research in Science Education 40 (4), 2010, pp 505-523

[14] Iskandarwassid, and $H$. DadangSunendar, "Strategipembelajaranbahasa". Bandung: PT RemajaRosdakarya, 2011

[15] Mulyasa, "Kurikulumtingkatsatuanpendidikan", Bandung: RemajaRosdakarya, 2006

[16] Mumpuni, $\quad$ K. $\quad$ E. $\quad$ (2013, October). Potensipendidikankeunggulanlokalberbasiskarakterdalampembelajaranbi ologi di indonesia. In Proceeding Biology Education Conference: Biology, Science, Enviromental, and Learning (Vol. 10, No. 2, pp. 7379).

[17] Poedjiadi, "Sainsteknologimasyarakat". Bandung: PT.RemajaRosdaKarya, 2005

[18] Subiantoro, A.W, "Pentingnyapraktikumdalampembelajaran IPA (Article)". Yogyakarta: UniversitasNegeri Yogyakarta, 2010

[19] Sugiono. 2008. Metodepenelitiankuantitatifkualitatifdan $R \& D$. Bandung: Alfabeta.

[20] Suparno, P, "MetodologipembelajaranFisika". Yogyakarta: UniversitasSanata Dharma, 2007

[21] Suja, I W., "Profilkompetensiketerampilanproses sainssiswasekolahdasar di KecamatanBuleleng." JurnalPendidikandanPengajaran IKIP NegeriSingaraja, 39(4), 2006, pp $204-218$ 